\title{
KAJIAN PENERAPAN EARMARKING CUKAI HASIL TEMBAKAU DI INDONESIA (PERIODE TAHUN 2006 S.D. 2016)
}

\author{
Renny Sukmono \\ Jurusan Kepabeanan dan Cukai, Politeknik Keuangan Negara STAN, Tangerang \\ Selatan, 15222 \\ E-mail: rhey.sukmo@gmail.com
}

\section{INFORMASI ARTIKEL}

Tanggal masuk

[25-04-2019]

Revisi

[25-04-2019]

Tanggal terima

[14-05-2019]
2.4\%. While unreceiver regents of $\mathrm{DBH} C \mathrm{CHT}$ poverty decrese averageis $2.1 \%$. For Economic growth average from 2012 to 2016, in the receiver regents of $D B H C H T$ is higher for about $4,44 \%$ and in unreceiver regents of DBH CHT is lower for about $3,69 \%$.

Key Words: DBH CHT, Earmarking, Unemployment Degree, Poverty Degree, and Economic Growth Degree.

\section{ABSTRAK}

Sebagai bentuk earmarking cukai hasil tembakau, pemerintah mengalokasikan Dana Bagi Hasil Cukai Hasil Tembakau (DBH CHT) ke sejumlah propinsi di Indonesia. Tujuan kebijakan ini adalah untuk mengendalikan konsumsi produk tembakau dan sekaligus membantu masyarakat umum yang berada di sekitar konsumen produk tembakau dan industri produk tembakau yang menanggung dampak negatif akibat produksi dan konsumsi produk tembakau. Namun, sampai dengan tahun 2016 proporsi penduduk yang menghisap/mengunyah tembakau makin meningkat. Pada daerah penerima alokasi DBH CHT memang terbukti jika tingkat penganggurannya lebih rendah dibandingkan dengan daerah bukan penerima. Rata-rata tingkat pengangguran dari tahun 2012 s.d 2016 cenderung meningkat. Namun rata-rata peningkatan pada daerah penerima lebih rendah dibandingkan daerah bukan penerima yaitu $6,756 \%$, sedangkan pada daerah bukan penerima sebesar $11,83 \%$. Di satu sisi, industri rokok dapat menyerap tenaga kerja, namun rokok menyebabkan dampak negatif yang tidak kalah hebat misalnya biaya kesehatan yang besar yang dikeluarkan baik oleh masyarakat maupun pemerintah dan turunnya produktifitas nasional. Sedangkan untuk rata-rata penurunan tingkat kemiskinan dari tahun 2012 s.d 2016, penerima alokasi DBH CHT memiliki rata-rata penurunan 
tingkat kemiskinan yang lebih besar jika dibandingkan daerah bukan penerima DBH CHT yaitu $2,4 \%$ sedangkan pada daerah bukan penerima turun rata-rata $2,1 \%$. Untuk rata-rata pertumbuhan ekonomi dari tahun 2012 s.d 2016 pada daerah penerima lebih besar jika dibandingkan dengan daerah bukan penerima, yaitu $4,44 \%$ sedangkan pada daerah bukan penerima sebesar $3,69 \%$.

Kata Kunci: DBH CHT, Earmarking, Tingkat Pengangguran, Tingkat Kemiskinan, dan Tingkat Pertumbuhan Ekonomi. 


\section{PENDAHULUAN}

\subsection{Latar Belakang}

Tujuan penerapan earmarking cukai hasil tembakau di Indonesia masih belum tercapai sampai dengan saat ini yaitu untuk mengendalikan konsumsi produk tembakau dan sekaligus membantu masyarakat umum yang berada di sekitar konsumen produk tembakau dan industri produk tembakau yang menanggung dampak negatif akibat produksi dan konsumsi produk tembakau. Proporsi penduduk yang menghisap dan mengunyah tembakau cenderung naik dari tahun ke tahun hampir di seluruh wilayah Indonesia. Seiring dengan hal ini, dampak negatif rokok pun juga semakin meningkat. Perokok pasif menanggung akibat yang tidak kalah parah dari ke lompok perokok aktif. Dampak negatif rokok tidak hanya pada perokok tetapi juga pada orang-orang di sekitarnya. Data World Health Organization (WHO) tahun 2014 menyatakan bahwa epidemi tembakau telah membunuh sekitar 6 juta orang per tahun, dimana 600ribu diantaranya adalah perokok pasif. Perokok membebankan biaya keuangan dan risiko fisik tidak hanya kepada dirinya sendiri tetapi juga orang lain. Seharusnya perokok sajalah yang menanggung semua "biaya" atau kerugian akibat merokok. Tetapi pada kenyataannya peroko membebankan secara fisik dan ekonomi kepada orang lain juga. Beban ini meliputi risiko orang lain yang terkena asap rokok di lingkungan sekitarnya dan biaya yang dibebankan pada masyarakat untuk pelayanan kesehatan.

WHO pada tahun 2008 telah memperkenalkan langkah-langkah yang dikenal dengan MPOWER sebagai aksi global untuk mengontrol konsumsi produk tembakau. MPOWER merupakan singkatan dari beberapa kebijakan yang dibuat oleh WHO, yaitu M untuk monitoring tobacco use and prevention policies (kebijakan pencegahan dan pemantauan penggunaan tembakau), $\mathrm{P}$ untuk protecting people from tobacco smoke (melindungi masyarakat dari rokok), $\mathrm{O}$ untuk offering help to quit tobacco use (menawarkan bantuan untuk berhenti menggunakan produk tembakau), $\mathrm{W}$ untuk warning about the dangers of tobacco (peringatan tentang bahaya produk tembakau), E untuk enforcing bans on tobacco advertising, promotion and sponsorship (menegakkan larangan iklan, promosi dan sponsor rokok), dan $\mathrm{R}$ untuk raising taxes on tobacco (menaikkan pajak atas produk tembakau). Langkah-langkah WHO inilah yang seharusnya dijadikan sumber acuan bagi negara-negara untuk mengantisipasi dan mengatasi dampak konsumsi produk tembakau.

Sementara itu, kebijakan earmarking yang diterapkan oleh pemerintah Indonesia sesuai dengan penjelasan pasal 66A ayat 1 Undang-Undang Nomor 39 Tahun 2007 tentang Cukai yaitu dengan memberikan Dana Bagi Hasil Cukai Hasil Tembakau (DBH CHT) kepada daerah karena barang kena cukai berupa hasil tembakau memiliki sifat atau karakteristik yang konsumsinya perlu dikendalikan dan diawasi serta memberikan dampak negatif bagi masyarakat. Penggunaan DBH CHT diarahkan untuk mendanai lima kegiatan utama yaitu (1) peningkatan kualitas tembakau sebagai bahan baku, (2) pengembangan industri tembakau, (3) pengembangan lingkungan sosial, (4) sosialisasi ketentuan cukai dan (5) pemberantasan barang kena cukai illegal. Sitepu, E.M.P (2016) menyatakan bahwa kebijakan yang sejalan dengan keinginan untuk mengendalikan konsumsi produk tembakau hanya pada poin ketiga yaitu pengembangan lingkungan sosial. Sebagai peraturan pelaksanaan dari pasal 66A ayat (1) Undang-Undang Nomor 39 
Tahun 2007 tentang cukai, pengggunaan DBH CHT diatur lebih lanjut dalam Peraturan Menteri Keuangan (PMK) Nomor 84/PMK.07/2008 sebagaimana telah diubah terakhir dengan PMK Nomor 28/PMK.07/2016 pasal 11 PMK tersebut mengatur tentang kegiatankegiatan pengembangan lingkungan sosial adalah sebagai berikut:

a. Pembinaan dan pelatihan keterampilan kerja bagi tenaga kerja dan masyarakat, penguatan sarana dan prasarana kelembagaan pelatihan, serta pelayanan penempatan tenaga kerja dan perluasan kesempatan kerja bagi pencari kerja.

b. Penyediaan/pemeliharaan sarana pelayanan kesehatan bagi masyarakat yang terkena penyakit akibat dampak konsumsi rokok dan penyakit lainnya.

c. Pembangunan/rehabilitasi/pemelihar aan jalan, saluran air limbah, sanitasi dan air bersih.

d. Penyediaan sarana dan prasarana pengolahan limbah industri hasil tembakau.

e. Penerapan sistem manajemen lingkungan bagi masyarakat di lingkungan industri hasil tembakau dan/atau penghasil bahan baku industri hasil tembakau.

f. Penguatan ekonomi masyarakat melalui kegiatan padat karya yang dapat mengentaskan kemiskinan, mengurangi pengangguran dan mendorong pertumbuhan ekonomi daerah.

Upaya pengendalian konsumsi produk tembakau telah dilakukan pemerintah, salah satunya dengan memberikan DBH CHT sejak tahun 2008. Pada tahun 2009 juga telah dikeluarkan PMK Nomor 20/PMK.07/2009 yang mengatur lebih detail tentang penggunaan DBH CHT. Pada peraturan tersebut dijelaskan bahwa kegiatan pembinaan lingkungan sosial meliputi: a. Pembinaan kemampuan dan keterampilan kerja masyarakat di lingkungan industri hasil tembakau dan/atau daerah penghasil bahan baku industri hasil tembakau.

b. Penerapan manajemen limbah industri hasil tembakau yang mengacu kepada analisis dampak lingkungan (AMDAL).

c. Penetapan Kawasan Tanpa Rokok dan pengadaan tempat khusus untuk merokok di tempat umum.

d. Peningkatan derajat kesehatan masyarakat dengan penyediaan fasilitas perawatan kesehatan bagi penderita akibat asap rokok.

e. Penguatan sarana dan prasarana kelembagaan pelatihan bagi tenaga kerja industri hasil tembakau, dan/atau penguatan ekonomi masyarakat di lingkungan industri hasil tembakau dalam rangka pengentasan kemiskinan, mengurangi pengangguran dan mendorong pertumbuhan ekonomi daerah, dilaksanakan antara lain melalui bantuan permodalan dan sarana produksi.

Namun, hal ini belum sesuai dengan apa yang diharapkan pemerintah, yaitu sesuai dengan data Riset Kesehatan Daerah (Riskesdas) diketahui bahwa dalam kurun waktu 9 tahun semenjak implementasi dana bagi hasil (earmarking) cukai hasil tembakau yaitu dari tahun 2008 sampai dengan 2016, eksternalitas negatif yang timbul akibat merokok justru semakin meningkat (lihat Gambar 1). 


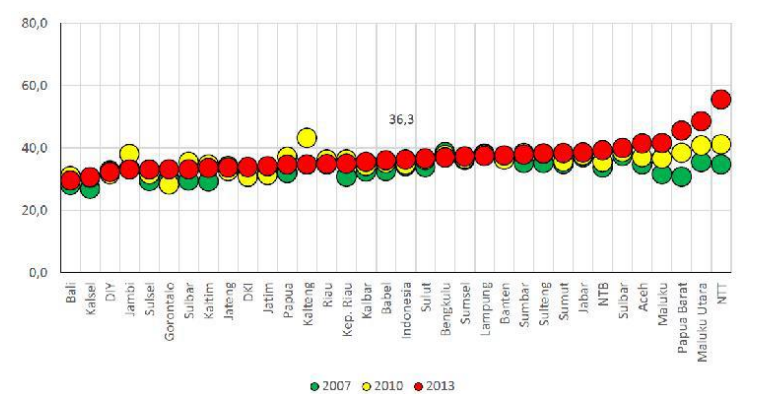

Gambar 1. Prevalensi Penduduk Berusia Minimal 15 Tahun Menurut Kebiasaan Merokok dan Mengunyah Tembakau Berdasarkan Propinsi di Indonesia Tahun 2007, 2010 dan 2013

Sumber: Riskedas, BPS

Gambar 1 menunjukkan bahwa proporsi penduduk yang berusia minimal 15 tahun yang merokok dan mengunyah tembakau cenderung meningkat. Tentunya hal ini bertolak belakang dengan tujuan earmarking cukai hasil tembakau. Sitepu, E.M.P (2016) menyatakan bahwa earmarking cukai di Indonesia melalui DBH CHT lebih cenderung digunakan untuk mendorong peningkatan produktifitas produk tembakau. Sehingga sangat wajar jika hal ini menjadi salah satu penyebab proporsi penduduk yang merokok atau mengunyah tembakau usia minimal 15 tahun semakin meningkat.

Berdasarkan laporan realisasi anggaran DBH CHT dari propinsi penerima yang diterima oleh DJPK, pada tahun 2016 realisasi anggaran yang terbesar dialokasikan pada kegiatan pembinaan lingkungan sosial dan terbesar kedua adalah peningkatan kualitas bahan baku. Pada komponen pembinaan lingkungan sosial, alokasi terbesar adalah digunakan oleh Dinas Kesehatan yaitu untuk menambah dan melengkapi fasilitas kesehatan untuk membantu orang-orang yang terkena dampak asap rokok. Namun, tidak dipungkiri bahwa ditemukan sejumlah kasus dimana fasilitas kesehatan yang diadakan kadang-kadang tidak berhubungan dengan penyakit akibat asap rokok. Penyediaan fasilitas kesehatan ini lebih menekankan pada upaya penanggulangan bukan pada upaya pencegahan. Untuk itu, dampak dari iklan rokok yang semakin gencar menjadi tidak lagi terbendung.

Dalam Peraturan Menteri Keuangan (PMK) Nomor 84/PMK.07/2008 sebagaimana telah diubah terakhir dengan PMK Nomor 28/PMK.07/2016 pasal 11 PMK yang mengatur kegiatan pengembangan sosial yang salah satu kegiatannya adalah penguatan ekonomi masyarakat melalui kegiatan padat karya yang dapat mengentaskan kemiskinan, mengurangi pengangguran dan mendorong pertumbuhan ekonomi daerah. Sesuai dengan realisasi anggaran alokasi DBH CHT tahun 2016, sebagian alokasi untuk program pembinaan lingkungan sosial adalah untuk memberikan pembinaan dan pelatihan keterampilan kerja bagi tenaga kerja dan masyarakat. Hal inilah yang mendorong peneliti untuk meneliti apakah alokasi DBH CHT mampu mendorong penguatan ekonomi masyarakat yang terindikasi melalui turunnya tingkat kemiskinan, menurunnya tingkat pengangguran dan meningkatnya pertumbuhan ekonomi di daerah.

Berdasarkan latar belakang yang telah diuraikan sebelumnya dapat dirumuskan permasalahan pada penelitian ini adalah bagaimanakah implementasi earmarking cukai hasil tembakau (DBH CHT) di Indonesia. Implementasi akan dilihat dari tiga kacamata yaitu dari tingkat pengangguran, tingkat kemiskinan, dan pertumbuhan ekonomi di provinsiprovinsi penerima. Untuk tujuan dari penelitian ini adalah untuk mengetahui bagaimana dampak pemberian alokasi DBH CHT terhadap provinsi-provinsi penerima. 


\section{LANDASAN TEORI}

\subsection{Dana Bagi Hasil Cukai Hasil Tembakau}

Penerimaan cukai dari tahun ke tahun terus mengalami peningkatan, walaupun pengenaan cukai tidak dimasukkan semata-mata untuk tujuan penerimaan negara. Berdasarkan data APBN 20052015, penerimaan cukai naik dari $\mathrm{Rp}$ 33,25 triliun pada tahun 2005 menjadi Rp 145,7 triliun pada tahun 2015 (terjadi kenaikan sebesar 438,23\%). Pada tahun 2007, pemerintah bersama-sama dengan Dewan Perwakilan Rakyat (DPR) mengeluarkan Undang-Undang Nomor 39 Tahun 2007 tentang cukai yang merupakan perubahan atas UndangUndang Nomor 11 Tahun 1995. Dalam Undang-Undang Nomor 39 Tahun 2007 diatur bahwa penerimaan cukai dari cukai hasil tembakau yang dibuat di Indonesia dibagikan kepada provinsi penghasil cukai hasil tembakau sebesar $2 \%$ yang digunakan untuk mendanai peningkatan kualitas bahan baku, pembinaan industri, pembinaan lingkungan sosial, sosialisasi ketentuan di bidang cukai, dan/atau pemberantasan barang kena cukai illegal (Pasal 66A ayat 1). Ketentuan sebagaimana tersebut sebelumnya mengenai dana bagi hasil cukai hasil tembakau tidak diatur dalam UndangUndang Nomor 11 Tahun 1995.

Penjelasan Pasal 66A ayat 1 UndangUndang Nomor 39 Tahun 2007 tentang Cukai mengatur bahwa cukai hasil tembakau yang dibuat di Indonesia dibagihasilkan kepada daerah karena barang kena cukai berupa hasil tembakau memiliki sifat atau karakteristik yang konsumsinya perlu dikendalikan dan diawasi serta memberikan dampak negatif bagi masyarakat dan mengoptimalkan upaya penerimaan negara dari cukai. Pengendalian dan pengawasan dilakukan oleh Pemerintah Pusat dan Pemerintah Daerah. Dana bagi hasil cukai merupakan bagian kapasitas fiskal yang perhitungannya disesuaikan dengan formula Dana Alokasi Umum (DAU) yang setiap tahun ditetapkan dalam pembahasan RAPBN. Selanjutnya, penjelasan Pasal 66A ayat 3 UndangUndang tersebut menguraikan bahwa pembagian, pengelolaan, dan penggunaan pembagian DBH CHT kepada kabupaten/kota penyumbang cukai hasil tembakau dan dihitung berdasarkan kontribusi penerimaan cukai hasil tembakaunya.

DBH CHT sebagian besar dialokasikan di tingkat kabupaten/kota dan bukan di tingkat provinsi. Dana earmarking cukai hasil tembakau berasal dari cukai yang dikenakan pada produk tembakau yang diproduksi di dalam negeri, dimana sebesar $2 \%$ didistribusikan ke provinsi penghasil tembakau. Dalam pengelolaan dan penggunaan dana tersebut, Gubernur mengatur distribusi dana untuk cukai tembakau kepada Bupati/Walikota di daerah masing-masing sesuai dengan kontribusi pendapatan cukai tembakau. Distribusi DBH CHT dilakukan berdasarkan persetujuan Menteri Keuangan (dengan menerbitkan Peraturan Menteri Keuangan), dengan komposisi $30 \%$ untuk provinsi penghasil, $40 \%$ untuk kabupaten/kota daerah penghasil, dan $30 \%$ untuk kabupaten/kota lainnya dalam provinsi tersebut. Dari total DBH CHT untuk periode 2008-2016 sebesar Rp15,095 triliun, provinsi hanya mendapatkan 30\% dari total atau Rp4,529 triliun. Sisanya $70 \%$ dialokasikan untuk kabupaten/kota yang memberikan kontribusi penerimaan cukai tembakau.

Perhitungan dana earmarking cukai hasil tembakau dialokasikan ke provinsi yang menghasilkan barang atau produk tembakau kena cukai (sebelum didistribusikan oleh Provinsi untuk Kabupaten/Kota) sebagaimana diatur dalam Peraturan Menteri Keuangan 
Nomor 145/PMK.07/2013 menggunakan pola sebagai berikut:

a. Variabel-variabel yang digunakan dalam menetapkan dasar pembagian DBH CHT yaitu: (i) persentase realisasi penerimaan cukai hasil tembakau tahun sebelumnya terhadap realisasi penerimaan cukai hasil tembakau nasional; (ii) persentase rata-rata produksi tembakau kering suatu provinsi selama 3 (tiga) tahun terakhir terhadap rata-rata produksi tembakau kering nasional; (iii) persentase invers Indeks Pembangunan Manusia suatu provinsi tahun sebelumnya terhadap invers Indeks Pembangunan Manusia seluruh provinsi penerima cukai hasil tembakau.

b. Tiap-tiap variabel ditetapkan dengan bobot sebagai berikut: (i) penerimaan cukai hasil tembakau sebesar 58\%; (ii) rata-rata produksi tembakau kering sebesar 38\%; (iii) persentase invers Indeks Pembangunan Manusia sebesar $4 \%$.

Sebagai peraturan pelaksanaan dari pasal 66A ayat (1) Undang-Undang Nomor 39 Tahun 2007 tentang Cukai, penggunaan DBH CHT diatur lebih lanjut dalam Peraturan Menteri Keuangan (PMK) Nomor 84/PMK.07/2008 sebagaimana telah diubah terakhir dengan PMK Nomor 28/PMK.07/2016. Pasal 11 PMK tersebut mengatur tentang kegiatankegiatan pembinaan lingkungan sosial sebagai berikut:

a. pembinaan dan pelatihan keterampilan kerja bagi tenaga kerja dan masyarakat;

b. penguatan sarana dan prasaran kelembagaan pelatihan, serta pelayanan penempatan tenaga kerja, dan perluasan kesempatan kerja bagi pencari kerja;

c. penyediaan/pemeliharaan sarana pelayanan kesehatan bagi masyarakat yang terkena penyakit akibat dampak konsumsi rokok dan penyakit lainnya;

d. pembangunan/rehabilitasi/pemelihar aan jalan, saluran air limbah, sanitasi, dan air bersih;

e. penyediaan sarana dan prasarana pengolahan limbah industri hasil tembakau;

f. penerapan sistem manajemen lingkungan bagi masyarakat di lingkungan industri hasil tembakau dan/atau penghasil bahan baku industri hasil tembakau; dan/atau

g. penguatan ekonomi masyarakat melalui kegiatan padat karya yang dapat mengentaskan kemiskinan, mengurangi pengangguran, dan mendorong pertumbuhan ekonomi daerah.

Kepala daerah bertanggung jawab terhadap penggunaan DBH CHT untuk program/kegiatan sebagaimana dimaksud dengan memperhatikan karakteristik daerah, yang meliputi:

a. provinsi penghasil cukai dan penghasil tembakau;

b. provinsi penghasil cukai;

c. provinsi penghasil tembakau;

d. kabupaten/kota penghasil cukai dan penghasil tembakau;

e. kabupaten/kota penghasil cukai;

f. kabupaten/kota penghasil tembakau; dan/atau

g. kabupaten/kota nonpenghasil.

\subsection{Tingkat Kemiskinan}

Untuk mengukur kemiskinan BPS menggunakan konsep kemampuan memenuhi kebutuhan dasar (basic need approach). Dengan pendekatan ini, kemiskinan dipandang sebagai ketidakmampuan dari sisi ekonomi untuk memenuhi kebutuhan dasar makanan dan bukan makanan yang diukur dari sisi pengeluaran. Jadi penduduk miskin adalah penduduk yang memiliki rata-rata pengeluaran per kapita per bulan di bawah garis kemiskinan. 
Garis kemiskinan merupakan penjumlahan dari Garis Kemiskinan Makanan (GKM) dan Garis Kemiskinan Non Makanan (GKNM). GKM merupakan nilai pengeluaran kebutuhan minimum makanan yang disetarakan dengan 2100 kalori perkapita per hari. Paket komoditi kebutuhan dasar makanan diwakili oleh 52 jenis komoditi (padipadian umbi-umbian, ikan, daging, telur dan susu, sayuran, kacang-kacangan, buah-buahan, minyak dan lemak, dll). GKNM merupakan kebutuhan minimum untuk perumahan, sandang, pendidikan dan kesehatan. Peket komoditi kebutuhan dasar non makanan diwakili oleh 51 jenis komoditi di perkotaan dan 47 jenis komoditi di pedesaan.

Persentase penduduk miskin ditunjukkan melalui penghitungan $\mathrm{Head}$ Count Index (HCI-P0) yang merupakan persentase penduduk yang berada di bawah garis kemiskinan (GK). Formulasi penghitungan persentase jumlah penduduk miskin adalah sebagai berikut:

$P_{\alpha}=\frac{1}{n} \sum_{i=1}^{q}\left[\frac{z-y_{i}}{z}\right]^{\alpha}$

Dimana:

$\alpha=0$

$\mathrm{z}=$ garis kemiskinan

$\mathrm{y}_{\mathrm{i}}=$ rata-rata pengeluaran per kapita sebulan penduduk yang berada di bawah garis kemiskinan $(\mathrm{i}=1,2,3, \ldots, \mathrm{q}) ; \mathrm{y}_{\mathrm{i}}<\mathrm{z}$ $\mathrm{q}$ = banyaknya penduduk yang berada di bawah garis kemiskinan

$\mathrm{n}=$ jumlah penduduk

\subsection{Tingkat Pengangguran}

Pengangguran secara luas dapat diartikan sebagai penduduk yang tidak bekerja tetapi sedang mencari pekerjaan atau sedang mempersiapkan suatu usaha baru atau penduduk yang tidak mencari pekerjaan karena sudah diterima bekerja tetapi belum mulai bekerja. Untuk mengetahui besar kecilnya tingkat pengangguran dapat dilakukan dengan menggunakan dua mekanisme yaitu:

a. Pendekatan Angkatan Kerja Besar kecilnya tingkat pengangguran dihitung berdasarkan persentase dari perbandingan jumlah antara orang menganggur dengan jumlah angkatan kerja.

b. Pendekatan Pemanfaatan Angkatan Kerja

Untuk menentukan besar kecilnya tingkat pengangguran berdasarkan pemanfaatan angkatan kerja dapat dilakukan melalui dua pendekatan yaitu:

1. Bekerja penuh (employed) yaitu orang-orang yang bekerja penuh atau jam kerjanya mencapai 35 jam per minggu.

2. Setengah menganggur (underemployed) yaitu mereka yang bekerja, tetapi belum dimanfaatkan secara penuh atau dengan kata lain jam kerjanya tidak mencapai 35 jam per minggu.

Menurut Case (2004) dalam bukunya prinsip-prinsip ekonomi makro, pengangguran dapat dibedakan dalam beberapa jenis yaitu:

a. Pengangguran Friksional

Pengangguran friksional adalah bagian pengangguran yang disebabkan oleh kerja normalnya pasar tenaga kerja. Istilah ini muncul pada percobaan pekerjaan atau keterampilan jangka pendek. Selain itu, pengangguran friksional juga muncul sebagai dampak dari perubahan persyaratan kerja seiring dengan dinamika ekonomi yang terjadi. Jenis pengangguran ini juga dapat terjadi karena berpindahpindahnya seseorang dari pekerjaan satu ke pekerjaan lainnya, sehingga menimbulkan jeda waktu menganggur.

b. Pengangguran Musiman

Pengangguran musiman adalah pengangguran yang terjadi pada 
masa-masa tertentu saja dalam satu tahun. Biasanya pengangguran ini terjadi di bidang pertanian, yaitu dimana masa bercocok tanam sedang menurun kesibukannya.

c. Pengangguran Siklis

Pengangguran siklis atau disebut juga pengangguran konjungtur adalah pengangguran yang diakibatkan oleh perubahan-perubahan dalam kegiatan perekonomian. Pada waktu kegiatan perekonomian mengalami kemunduran, perusahaan harus mengurangi jumlah produksinya. Hal ini berdampak pada pengurangan jam kerja pegawai, mesin yang ada sebagian tidak dioperasikan sehingga sebagian pekerja diberhentikan.

d. Pengangguran Struktural

Pengangguran struktural terjadi karena sifatnya yang mendasar, yaitu dimana para pencari kerja tidak bisa memenuhi persyaratan yang dibutuhkan untul lowongan pekerjaan yang tersedia. Hal ini bisa terjadi karena perkembangan ekonomi yang sangat pesat atau makin rumitnya proses produksi yang digunakan.

Sedangkan terdapat 4 bentuk pengangguran antara lain:

1. Pengangguran terbuka (open unemployment) adalah mereka yang mampu dan sering kali sangat ingin bekerja tetapi tidak tersedia pekerjaan yang cocok dengan mereka.

2. Setengah menganggur (under employment) adalah mereka yang secara nominal bekerja penuh namun produktifitasnya rendah sehingga pengurangan jam kerjanya tidak mempunyai arti atau produksi secara keseluruhan.

3. Tenaga kerja yang lemah (impaired) adalah mereka yang mungkin bekerja penuh tetapi intensitasnya lemah karena kurang gizi atau penyakitan.

4. Tenaga kerja yang tidak produktif adalah mereka yang bekerja namun tidak menghasilkan sesuatu yang baik.

\subsection{Pertumbuhan Ekonomi}

Pertumbuhan ekonomi menurut Budiono (1999) merupakan proses kenaikan kapasitas produksi dalam suatu perekonomian secara berkesinambungan menuju kearah yang lebih baik yang diwujudkan ke dalam bentuk kenaikan pendapatan nasional (Produk Domestik Bruto) maupun pendapatan daerah (Produk Domestik Regional Bruto) dalam jangka panjang. Pertumbuhan ekonomi disini meliputi tiga aspek yaitu: (i) pertumbuhan ekonomi merupakan suatu proses (aspek ekonomis) suatu perekonomian berkembang, berubag dari waktu ke waktu; (ii) pertumbuhan ekonomi berkaitan dengan adanya kenaikan output perkapita, dalam hal ini ada dua aspek penting yaitu output total dan jumlah penduduk. Output perkapita adalah output total dibagi jumlah penduduk; (iii) pertumbuhan ekonomi dikaitkan dengan perspektif jangka panjang. Sedangkan PDRB menurut Badan Pusat Statistik (BPS) merupakan jumlah nilai tambah yang dihasilkan oleh seluruh unit produksi, baik berupa barang dan jasa dalam suatu wilayah.

Terdapat dua acara perhitungan PDRB, yaitu mekanisme atas dasar harga berlaku dan mekanisme atas dasar harga konstan. PDRB atas dasar harga berlaku menggambarkan nilai tambah barang dan jasa yang dihitung menggunakan harga pada setiap tahunnya, digunakan untuk menunjukkan besarnya struktur perekonomian dan peranan sektor ekonomi yang ada. Sedangkan PDRB atas harga dasar konstan menggambarkan nilai tambah barang dan jasa yang dihitung menggunakan harga pada tahun tertentu sebagai dasar acuan yang ada, digunakan untuk melihat pola pertumbuhan dari tahun ke tahun. 
Pertumbuhan ekonomi dipengaruhi oleh dua faktor yaitu faktor ekonomi dan faktor non-ekonomi. Faktor ekonomi meliputi sumber alam, modal, organisasi, kemajuan teknologi, pembagian kerja dan skala produksi. Sedangkan faktor nonekonomi meliputi faktor sosial, faktor sumber daya manusia, faktor politik dan faktor administratif.

Untuk mengetahui maju tidaknya suatu perekonomian diperlukan adanya suatu alat pengukur yang tepat. Alat pengukur pertumbuhan perekonomian ada beberapa macam diantaranya:

a. Produk Domestik Bruto (PDB)

Produk Domestik Bruto merupakan jumlah barang dan jasa akhir yang dihasilkan oleh suatu perekonomian dalam satu tahun dan dinyatakan dalam harga pasar.

b. Produk Domestik Bruto Per Kapita Produk Domestik Bruto Per Kapita merupakan jumlah PDB nasional dibagi dengan jumlah penduduk atau dapat disebut dengan PDB rata-rata atau PDB per kepala.

c. Pendapatan Per Jam Kerja

Pendapatan Per Jam Kerja merupakan upah atau pendapatan yang dihasilkan per jam kerja. Biasanya suatu negara yang mempunyai tingkat upah per jam lebih tinggi daripada negara lain, boleh dikatakan bahwa negara tersebut lebih maju dibandingkan negara lain.

\section{METODE PENELITIAN}

\subsection{Jenis dan Sumber Data}

Penelitian ini menggunakan datadata sekunder yang diterbitkan oleh beberapa instansi yaitu:

Tabel 1

Data yang Digunakan dan Sumbernya

\begin{tabular}{|c|l|c|}
\hline No & \multicolumn{1}{|c|}{ Data } & $\begin{array}{c}\text { Instansi } \\
\text { Penerbit }\end{array}$ \\
\hline 1 & $\begin{array}{l}\text { Tingkat } \\
\text { Kemiskinan }\end{array}$ & BPS \\
\hline
\end{tabular}

\begin{tabular}{|c|c|c|}
\hline & $\begin{array}{l}\text { Provinsi di } \\
\text { Indonesia tahun } \\
2015 \text { dan tahun } \\
2016\end{array}$ & \\
\hline 2 & $\begin{array}{l}\text { Tingkat } \\
\text { Pengangguran } \\
\text { Provinsi di } \\
\text { Indonesia tahun } \\
2015 \text { dan tahun } \\
2016\end{array}$ & BPS \\
\hline 3 & $\begin{array}{l}\text { Produk Domestik } \\
\text { Bruto Atas Dasar } \\
\text { Harga Konstan } \\
\text { Provinsi di } \\
\text { Indonesia Tahun } \\
2015 \text { dan Tahun } \\
2016\end{array}$ & BPS \\
\hline 4 & $\begin{array}{l}\text { Riset Kesehatan } \\
\text { Dasar Tahun } 2007 \\
\text { dan Tahun } 2013\end{array}$ & $\begin{array}{c}\text { Kemenkes } \\
\text { RI }\end{array}$ \\
\hline 5 & $\begin{array}{l}\text { Laporan Realisasi } \\
\text { Penggunaan DBH } \\
\text { CHT Per Program } \\
\text { Tahun } 2016\end{array}$ & $\begin{array}{c}\text { DJPK - } \\
\text { Kemenkeu } \\
\text { RI }\end{array}$ \\
\hline
\end{tabular}

Provinsi penerima pada penelitian ini adalah provinsi-provinsi yang menerima alokasi DBH CHT.

\subsection{Definisi Operasional Variabel}

Variabel-variabel yang digunakan pada penelitian ini adalah sebagai berikut:

Tabel 2

Definisi Operasional Variabel

\begin{tabular}{|l|l|}
\hline \multicolumn{1}{|c|}{ Variabel } & \multicolumn{2}{|c|}{ Definisi } \\
\hline Perubahan & Selisih Tingkat \\
Tingkat & Pengangguran per \\
Pengangguran & Februari 2016 dengan \\
& Tingkat \\
& Pengangguran Per \\
& Agustus 2016 \\
\hline Perubahan & Selisih Tingkat \\
Tingkat & Kemiskinan per Maret \\
Kemiskinan & 2016 dengan Tingkat \\
& Kemiskinan Per \\
& September 2016 \\
\hline
\end{tabular}




\begin{tabular}{|c|c|}
\hline $\begin{array}{l}\text { Pertumbuhan } \\
\text { Ekonomi }\end{array}$ & $\begin{array}{lcc}\text { Selisih } & \text { PDB } & \text { ADHK } \\
\text { pada tahun } 2016 \\
\text { dengan tahun } 2017\end{array}$ \\
\hline
\end{tabular}

\subsection{Metode Analisis Data}

Metode analisis yang digunakan dalam penelitian adalah gabungan antara metode kuantitatif dan kualitatif. Metode kuantitatif yang digunakan adalah dengan melihat deskriptif statistik data dan uji beda rata-rata menggunakan uji rata-rata untuk dua sampel yang saling bebas, yaitu untuk menguji perbedaaan antara ratarata periode tertentu dengan periode sebelumnya. Dua sampel acak yang bebas berukuran masing-masing $\mathrm{n}_{1}$ dan $\mathrm{n}_{2}$ diambil dari dua populasi dengan rataan $\mu_{1}$ dan $\mu_{2}$ dan variansi $\sigma_{1}^{2}$ dan $\sigma_{2}^{2}$. Terdapat beberapa alternatif pengujian dua rataan berdasarkan diketahui atau tidaknya variansi. Langkah-langkah dalam melakukan uji dua rataan adalah sebagai berikut:

\section{- Menentukan hipotesis}

$\mathrm{H}_{0} \quad: \mu_{1}-\mu_{2}=d_{0}$

$$
\begin{array}{ll}
\mathrm{H}_{1} & : \mu_{1}-\mu_{2} \neq d_{0} \\
\text { atau } & \\
\mathrm{H}_{0} & : \mu_{1}-\mu_{2}=d_{0} \\
\mathrm{H}_{1} & : \mu_{1}-\mu_{2}>d_{0} \\
\text { atau } & \\
\mathrm{H}_{0} & : \mu_{1}-\mu_{2}=d_{0} \\
\mathrm{H}_{1} & : \mu_{1}-\mu_{2}<d_{0}
\end{array}
$$

Pengamatan Berpasangan:

$\mathrm{H}_{0} \quad: \mu_{D}=d_{0}$

$\mathrm{H}_{1} \quad: \mu_{D}<d_{0}$

- Menentukan tingkat keyakinan

Tingkat keyakinan adalah seberapa besar keyakinan peneliti bahwa kesimpulan yang dihasilkan adalah benar.

- Menentukan daerah kritis

Derah kritis merupakan sebuah interval yang memberikan petunjuk bagi peneliti untuk menerima atau menolak hipotesis.

- Menentukan Statistik Uji

\begin{tabular}{|c|c|c|c|c|}
\hline No & $\mathrm{H}_{0}$ & Nilai Statistik Uji & $\mathrm{H}_{1}$ & Daerah Kritis \\
\hline 1 & $\begin{array}{l}\mu_{1}-\mu_{2} \\
=d_{0}\end{array}$ & $\begin{array}{l}\text { Variansi Diketahui } \\
z z=\frac{\left(\bar{x}_{1}-\bar{x}_{2}\right)-d_{0}}{\sqrt{\left(\sigma_{1}^{2} / n_{1}\right)+\left(\sigma_{2}^{2} / n_{2}\right)}}\end{array}$ & $\begin{array}{l}\mu_{1}-\mu_{2}<d_{0} \\
\mu_{1}-\mu_{2}>d_{0} \\
\mu_{1}-\mu_{2} \neq d_{0}\end{array}$ & $\begin{array}{c}z<-z_{\alpha} \\
z>z_{\alpha} \\
z<-z_{\alpha / 2} \text { atau } \\
z>z_{\alpha / 2}\end{array}$ \\
\hline 2 & $\begin{array}{l}\mu_{1}-\mu_{2} \\
=d_{0}\end{array}$ & $\begin{array}{l}\text { Varians Tidak Diketahui dan } \\
\text { Dianggap Sama } \\
t=\frac{\left(\bar{x}_{1}-\bar{x}_{2}\right)-d_{0}}{s_{p} \sqrt{\left(1 / n_{1}\right)+\left(1 / n_{2}\right)}} \\
\quad \mathrm{v}=n_{1}+n_{2}-2 \\
s_{p}^{2} \\
=\frac{\left(n_{1}-1\right) s_{1}^{2}+\left(n_{2}-1\right) s_{2}^{2}}{n_{1}+n_{2}-2}\end{array}$ & $\begin{array}{l}\mu_{1}-\mu_{2}<d_{0} \\
\mu_{1}-\mu_{2}>d_{0} \\
\mu_{1}-\mu_{2} \neq d_{0}\end{array}$ & $\begin{array}{c}t<-t_{\alpha} \\
t>t_{\alpha} \\
t<-t_{\alpha / 2} \text { atau } \\
t>t_{\alpha / 2}\end{array}$ \\
\hline 3 & $\begin{array}{l}\mu_{1}-\mu_{2} \\
=d_{0}\end{array}$ & $\begin{array}{l}\text { Varians Tidak Diketahui dan } \\
\text { dianggap Berbeda }\end{array}$ & $\mu_{1}-\mu_{2}<d_{0}$ & $t<-t_{\alpha}$ \\
\hline
\end{tabular}

- Penarikan kesimpulan

Tabel untuk statistik uji dan daerah kritis untuk setiap karakteristik pada uji dua rataan disajikan pada Tabel 3 .

Tabel 3

Statistik Uji dan Daerah Kritis Uji Dua Rataan 


\begin{tabular}{|c|c|c|c|c|}
\hline No & $\mathrm{H}_{0}$ & Nilai Statistik Uji & $\mathrm{H}_{1}$ & Daerah Kritis \\
\hline & & $t=\frac{\left(\bar{x}_{1}-\bar{x}_{2}\right)-d_{0}}{\sqrt{\left(s_{1}^{2} / n_{1}\right)+\left(s_{2}^{2} / n_{2}\right)}}$ & $\mu_{1}-\mu_{2}>d_{0}$ & $t>t_{\alpha}$ \\
& & $\mu_{1}-\mu_{2} \neq d_{0}$ & $t<-t_{\alpha / 2}$ atau \\
$t>t_{\alpha / 2}$ \\
\end{tabular}

\section{ANALISIS DATA DAN PEMBAHASAN}

Pada Bagian Analisis dan Pembahasan ini akan dilihat bagaimanakah pengaruh rokok di Indonesia dari tahun ke tahun dan selanjutnya akan dilihat bagimanakah dampak pemberian DBH CHT kepada provinsi-provinsi penerima alokasi $\mathrm{DBH}$ CHT.

\section{1 "Perokok" di Indonesia}

Gambar 2 menunjukkan bahwa sebelum adanya kebijakan pengalokasian DBH CHT pada tahun 2008, berdasarkan beberapa riset yang dilakukan oleh Kementerian Kesehatan dapat diketahui bahwa prevelensi perokok remaja mengalami kenaikan, dari $7,1 \%$ pada tahun 1995 naik menjadi $12,7 \%$. Peningkatan prevelensi perokok remaja masih berlanjut pada survey tahun 2004 yaitu menjadi $17,3 \%$ dan naik kembali pada tahun 2007 sebesar 18,8\%.

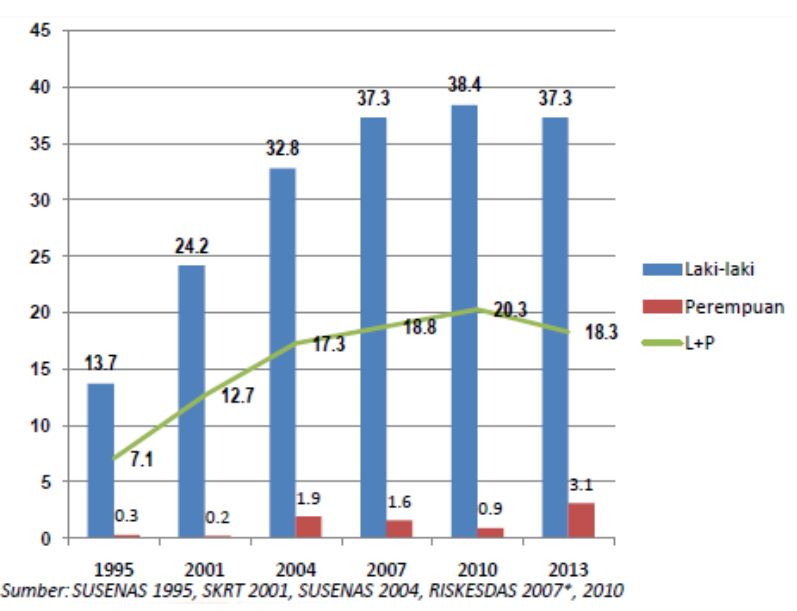

Gambar 2. Prevelensi Perokok Remaja (15-19 Tahun)

Dari tahun 2010 sampai tahun 2013 prevelensi perokok remaja mengalami penurunan yaitu dari $20,3 \%$ menjadi 18,3 $\%$. Namun dapat dilihat bahwa prevelensi perokok pada perempuan mengalami kenaikan yaitu dari $0,9 \%$ menjadi $3,1 \%$. Kenaikan yang cukup signifikan dibandingkan dengan kenaikan prevelensi perokok perempuan pada tahun-tahun sebelumnya.

Hal yang tidak kalah mengkhawatirkan adalah proporsi perokok pemula yaitu perokok yang berusia 10 sampai dengan 14 tahun. Dapat dilihat pada Gambar 3 dari tahun 1995 sampai dengan tahun 2013 perokok 
pemula cenderung meningkat. Kenaikan paling tinggi terjadi pada tahun $2010 \mathrm{ke}$ tahun 2013 yaitu sebesar 7,2\%.

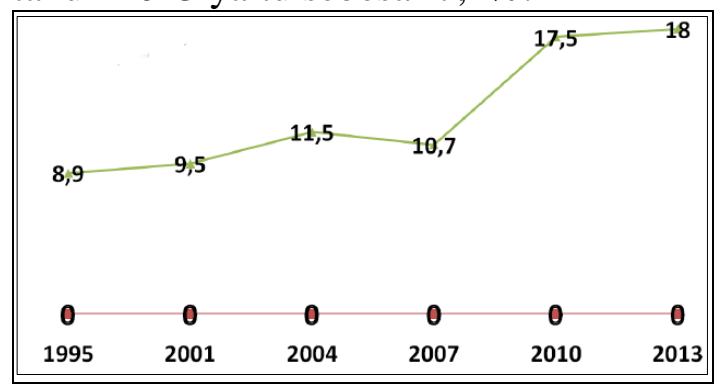

Gambar 3. Proporsi Perokok Pemula Usia 10-14 Tahun

Pemerintah Indonesia harus segera mewaspadai kondisi-kondisi yang cukup mengkhawatirkan ini. Dapat dilihat bahwa dari tahun ke tahun perokok pemula (usia 10-14 tahun) semakin meningkat. Selain iu juga tentang trend usia mulai merokok, berdasarkan hasil Riskesdas tahun 2007, tahun 2010 dan tahun 2013 diketahui bahwa proporsi paling tinggi penduduk mulai merokok di usia remaja yaitu dari usia 15 tahun sampai dengan 19 tahun. Masa dimana kebanyakan penduduk berada pada jenjang pendidikan SLTA. Jika pada usia ini sudah membiasakan untuk merokok, kebiasaan ini akan terbawa sampai dewasa.

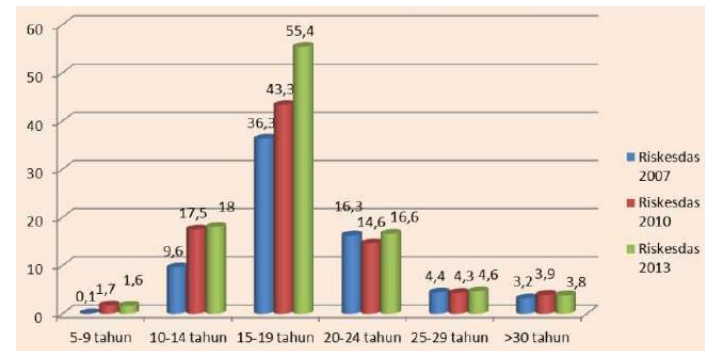

Gambar 4. Trend Usia Mulai Merokok

Sumber Rikesdas Tahun 2007, Tahun 2010 dan Tahun 2013.

Tabel 4 menunjukkan bahwa pada daerah yang menerima alokasi DBH CHT, dari 17 provinsi yang menerima alokasi terdapat lima provinsi yang mengalami kenaikan proporsi penduduk yang merokok. Kenaikan paling tinggi terjadi pada Provinsi Kepualauan Riau yaitu sebesar 3,7\%. 12 daerah penerima DBH CHT yang lain, proporsi penduduk yang merokok cenderung turun.

Tabel 4

Proporsi Penduduk Merokok Usia (15 tahun ke atas) pada Provinsi Penerima DBH CHT Berdasarkan Rikesdas Tahun 2007 dan Tahun 2013

\begin{tabular}{|c|l|c|c|c|}
\hline No & \multicolumn{1}{|c|}{ Propinsi } & $\begin{array}{l}\text { Tahun } \\
2007\end{array}$ & $\begin{array}{c}\text { Tahun } \\
2013\end{array}$ & Keterangan \\
\hline 1 & Aceh & 29.7 & 29.3 & Turun \\
\hline 2 & Sumatera Utara & 28.8 & 28.4 & Turun \\
\hline 3 & Sumatera Barat & 30.2 & 30.3 & Naik \\
\hline 4 & Jambi & 29.5 & 27.6 & Turun \\
\hline 5 & Sumatera Selatan & 31.7 & 30.1 & Turun \\
\hline 6 & Lampung & 34.4 & 31.3 & Turun \\
\hline 7 & Kepulauan Riau & 27.0 & 30.7 & Naik \\
\hline 8 & Jawa Barat & 32.4 & 32.7 & Naik \\
\hline 9 & Jawa Tengah & 30.7 & 28.2 & Turun \\
\hline 10 & DI Yogyakarta & 29.8 & 26.9 & Turun \\
\hline 11 & Jawa Timur & 29.1 & 28.9 & Turun \\
\hline 12 & Bali & 24.9 & 22.4 & Turun \\
\hline 13 & Nusa Tenggara Barat & 30.1 & 30.3 & Naik
\end{tabular}




\begin{tabular}{|c|l|c|c|c|}
14 & $\begin{array}{l}\text { Nusa Tengggara } \\
\text { Timur }\end{array}$ & 28.7 & 25.9 & Turun \\
\hline 15 & Kalimantan Tengah & 28.9 & 26.5 & Turun \\
\hline 16 & Sulawesi Tengah & 30.7 & 30.7 & Tetap \\
\hline 17 & Sulawesi Selatan & 25.5 & 27 & Naik \\
\hline
\end{tabular}

Sumber: Diolah dari Hasil Rikesdas Tahun 2007 dan Tahun 2013

Pengendalian perokok yang menghasilkan asap rokok yang sangat berbahaya bagi kesehatan perokok aktif maupun perokok pasif adalah dengan menghirup udara bersih tanpa paparan asap rokok atau biasa disebut dengan penetapan Kawasan Tanpa Rokok (KTR). Penetapan KTR dan pengadaan tempat khusus untuk merokok di tempat umum merupakan salah satu kegiatan yang dibiayai oleh DBH CHT sesuai dengan PMK Nomor 20/PMK.07/2009. Penerapan KTR sebenarnya selama ini telah banyak diupayakan oleh instansi pemerintah maupun swasta dan masyarakat. Namun, upaya tersebut masih jauh tertinggal dibandingkan dengan penjualan, periklanan/promosi rokok. Dari 17 provinsi yang mendapatkan alokasi DBH CHT, seluruhnya sudah memiliki peraturan terkait penetapan KTR. Tabel 5 menunjukkan data peraturan KTR provinsi penerima DBH CHT.

Tabel 5

Daftar Provinsi Penerima DBH CHT yang Memiliki Peraturan KTR

\begin{tabular}{|c|l|c|c|}
\hline No & \multicolumn{1}{|c|}{ Propinsi } & $\begin{array}{c}\text { Banyak } \\
\text { Kabupaten }\end{array}$ & $\begin{array}{c}\text { Peraturan } \\
\text { KTR }\end{array}$ \\
\hline 1 & Aceh & 23 & 3 \\
\hline 2 & Sumatera Utara & 33 & 6 \\
\hline 3 & Sumatera Barat & 19 & 10 \\
\hline 4 & Jambi & 11 & 8 \\
\hline 5 & Sumatera Selatan & 17 & 7 \\
\hline 6 & Lampung & 15 & 13 \\
\hline 7 & Kepulauan Riau & 7 & 4 \\
\hline 8 & Jawa Barat & 27 & 16 \\
\hline 9 & Jawa Tengah & 35 & 14 \\
\hline 10 & DI Yogyakarta & 5 & 5 \\
\hline 11 & Jawa Timur & 38 & 9 \\
\hline 12 & Bali & 9 & 8 \\
\hline 13 & Nusa Tenggara Barat & 10 & 6 \\
\hline 14 & Nusa Tengggara Timur & 22 & 7 \\
\hline 15 & Kalimantan Tengah & 14 & 9 \\
\hline 16 & Sulawesi Tengah & 13 & 6 \\
\hline 17 & Sulawesi Selatan & 24 & 20 \\
\hline Total & & $\mathbf{3 2 2}$ & $\mathbf{1 5 1}$ \\
\hline
\end{tabular}


Nizwardi Azkha (2013) menyatakan bahwa KTR tanpa adanya komitmen dan dukungan dari semua pihak sulit untuk penerapan KTR. Dapat dilihat pada Tabel 5 dari 150 peraturan yang telah ditetapkan, hanya 63 (42\%) peraturan yang diimplementasikan. Belum ditambah dengan masih lemahnya pengawasan terhadap implementasi peraturan tentang KTR. Rendahnya komitmen dan kesadaran dari semua pihak inilah yang menyebabkan upaya penurunan jumlah perokok aktif dan perokok pasif masih menjadi pekerjaan rumah yang besar bagi Pemerintah Indonesia. Pada sambutan Menteri Kesehatan Nila F. Moeloek di $4^{\text {th }}$ Indonesian Conference on Tobacco or Health di Jakarta pada Senin, 15 Mei 2017 dinyatakan bahwa "Angka yang merokok di Indonesia selalu meningkat. Tahun 2013 sebanyak 36\% dan pada tahun 2016 sebanyak $54 \%$ yang merokok". Hal ini tentu merupakan sesuatu yang kritis mengingat lebih dari separuh jumlah warga negara Indonesia adalah perokok.

Pada tahun 2016 Kementerian Keuangan melalui Direktorat Jenderal Perimbangan Keuangan sesuai dengan PMK Nomor 47/PMK.07/2016 tentang Rincian Dana Bagi Hasil Cukai Hasil Tembakau Menurut Provinsi/ Kabupaten/ Kota Tahun Anggaran 2016 telah menggelontorkan anggaran sebesar Rp2.796.355.150.000,00 yang akan didistribusikan kepada 16 provinsi penerima. Pada tahun 2016 provinsi Kalimantan Tengah tidak mendapatkan alokasi DBH CHT. Dana bagi hasil ini digunakan untuk membiayai lima program utama yaitu peningkatan kualitas bahan baku, pembinaan industri, pembinaan lingkungan sosial, sosialisasi ketentuan di bidang cukai dan pemberantasan barang kena cukai illegal. Rincian alokasi anggaran DBH CHT pada pada setiap propinsi disajikan pada Tabel 6.

Tabel 6

Alokasi DBH CHT Pada Setiap Provinsi Penerima

\begin{tabular}{|c|l|r|}
\hline No & \multicolumn{1}{|c|}{ Propinsi } & Alokasi DBH CHT \\
\hline 1 & Aceh & $17,395,331,000.00$ \\
\hline 2 & Sumatera Utara & $22,941,233,000.00$ \\
\hline 3 & Sumatera Barat & $13,360,571,000.00$ \\
\hline 4 & Jambi & $10,169,454,000.00$ \\
\hline 5 & Sumatera Selatan & $8,808,602,000.00$ \\
\hline 6 & Lampung & $12,906,963,000.00$ \\
\hline 7 & Kepulauan Riau & $5,981,594,000.00$ \\
\hline 8 & Jawa Barat & $318,596,988,000.00$ \\
\hline 9 & Jawa Tengah & $633,688,108,000.00$ \\
\hline 10 & DI Yogyakarta & $19,977,448,000.00$ \\
\hline 11 & Jawa Timur & $1,439,397,008,000.00$ \\
\hline 12 & Bali & $12,439,751,000.00$ \\
\hline 13 & Nusa Tenggara Barat & $241,405,196,000.00$ \\
\hline 14 & Nusa Tengggara Timur & $15,249,112,000.00$ \\
\hline 15 & Sulawesi Tengah & $7,485,170,000.00$ \\
\hline 16 & Sulawesi Selatan & $16,552,621,000.00$ \\
\hline
\end{tabular}


Sesuai dengan PMK Nomor 28/PMK.07/2016, salah satu kegiatan yang dilakukan dalam program pembinaan lingkungan sosial adalah pembinaan dan pelatihan keterampilan kerja bagi tenaga kerja dan masyarakat, penguatan sarana dan prasarana kelembagaan pelatihan, serta pelayanan penempatan tenaga kerja dan perluasan kesempatan kerja bagi pencari kerja. Kegiatan pembinaan kemampuan dan keterampilan kerja bagi tenaga kerja dan masyarakat meliputi:

a. Pelatihan berbasis kompetensi, termasuk uji/sertifikasi kompetensi.

b. pemberdayaan masyarakat melalui kewirausahaan, termasuk pembentukan dan pembinaan Usaha Mandiri Sektor Informal, pembinaan Tenaga Kerja Mandiri, pembinaan padat karya produktif, pembinaan terapan Teknologi Tepat Guna, pembinaan Tenaga Kerja Pemuda Mandiri Profesional, pendayagunaan Tenaga Kerja Sarjana.

c. Bantuan sarana produksi dan fasilitasi promosi bagi usaha mandiri masyarakat.

Sedangkan untuk kegiatan penguatan sarana dan kelembagaan pelatihan meliputi kegiatan antara lain sebagai berikut:

a. Pembangunan dan revitalisasi Balai Latihan Kerja (BLK).

b. Revitalisasi atau pengadaan sarana/peralatan pendukung pelatihan di BLK.

Untuk kegiatan pelayanan penempatan tenaga kerja dan perluasan kesempatan kerja bagi pencari kerja meliputi kegiatan antara lain pemberian informasi lowongan pekerjaan, penyuluhan kerja, penempatan eks siswa BLK dan magang kerja dalam negeri.

Dalam RUU APBN 2016 disebutkan penerimaan DBH CHT, baik bagian provinsi maupun bagian kabupaten/kota, dialokasikan dengan dua ketentuan, yakni pertama, paling sedikit 50\% untuk mendanai peningkatan kualitas bahan baku, pembinaan industri, pembinaan lingkungan sosial, sosialisasi ketentuan di bidang cukai, dan/atau pemberantasan barang kena cukai ilegal. Kedua, paling banyak 50\% untuk mendanai kegiatan sesuai dengan kebutuhan dan prioritas daerah. Meskipun tidak berkaitan langsung dengan tembakau, pemanfaatan DBH CHT ini harus mengedepankan kegiatan yang bertujuan untuk mengurangi tingkat kemiskinan, mengurangi pengangguran dan mendorong pertumbuhan ekonomi daerah.

Penggunaan DBH CHT dibedakan menjadi dua jenis yaitu specific grant dan block grant. Specific Grant merupakan anggaran yang alokasi kegiatannya sudah ditentukan oleh pemerintah dalam hal ini adalah Kementerian Keuangan. Sedangkan Block Grant adalah anggaran yang penggunaannya diserahkan kepada pemerintah daerah dan penggunaannya bersifat umum. Pada tahun 2016, realisasi Spesific Grant DBH CHT (dalam persentase) pada masing-masing propinsi adalah sebagai berikut:

Tabel 7

Realisasi DBH CHT Pada Setiap Propinsi Penerima pada Masing-Masing Program

\begin{tabular}{|c|c|c|c|c|c|c|c|}
\hline \multirow{2}{*}{ No } & \multirow{2}{*}{ Nama Daerah } & \multicolumn{5}{|c|}{ Program } & \multirow{2}{*}{ Total } \\
\hline & & 1 & 2 & 3 & 4 & 5 & \\
\hline 1 & Provinsi Aceh & 83.31 & 0.00 & 12.61 & 4.08 & 0.00 & 100.00 \\
\hline 2 & Provinsi Sumatera Utara & - & - & - & - & - & - \\
\hline 3 & Provinsi Sumatera Barat & 34.99 & 0.00 & 61.03 & 3.98 & 0.00 & 100.00 \\
\hline
\end{tabular}




\begin{tabular}{|c|l|c|c|c|c|c|c|}
4 & Provinsi Jambi & 65.09 & 0.00 & 34.91 & 0.00 & 0.00 & 100.00 \\
\hline 5 & Provinsi Sumatera Selatan & - & - & - & - & - & - \\
\hline 6 & Provinsi Lampung & 98.89 & 0.00 & 1.11 & 0.00 & 0.00 & 100.00 \\
\hline 7 & Provinsi Jawa Barat & 7.56 & 0.12 & 90.27 & 0.93 & 1.12 & 100.00 \\
\hline 8 & Provinsi Jawa Tengah & 10.05 & 1.94 & 85.10 & 2.22 & 0.68 & 100.00 \\
\hline 9 & Provinsi DI Yogyakarta & 15.51 & 2.07 & 79.86 & 2.38 & 0.19 & 100.00 \\
\hline 10 & Provinsi Jawa Timur & 8.55 & 6.04 & 83.06 & 2.05 & 0.31 & 100.00 \\
\hline 11 & Provinsi Bali & 63.64 & 0.00 & 35.98 & 0.38 & 0.00 & 100.00 \\
\hline 12 & Provinsi NTB & 30.09 & 0.00 & 68.81 & 1.08 & 0.03 & 100.00 \\
\hline 13 & Provinsi NTT & 97.29 & 0.00 & 0.00 & 2.71 & 0.00 & 100.00 \\
\hline 14 & Provinsi Kepulauan Riau & - & - & - & - & - & - \\
\hline 15 & Provinsi Sulawesi Selatan & 36.65 & 0.48 & 54.93 & 5.47 & 2.47 & 100.00 \\
\hline 16 & Provinsi Sulawesi Tengah & 0.00 & 0.00 & 93.75 & 4.20 & 2.05 & 100.00 \\
\hline
\end{tabular}

Keterangan:

Kode 1: Peningkatan kualitas bahan baku

Kode 2: Pembinaan industri

Kode 3: Pembinaan lingkungan sosial

Kode 4: Sosialisasi ketentuan di bidang cukai

Kode 5: Pemberantasan barang kena cukai illegal

*kolom kosong bukan karena tidak ada realisasi tetapi karena propinsi belum melaporkan realisasi ke DJPKKementerian Keuangan.

Tabel 7 menunjukkan bahwa dari 13 propinsi yang sudah melaporkan realisasi penggunaan DBH CHT, delapan propinsi di antaranya menggunakan DBH CHT dengan proporsi paling besar pada kegiatan pembinaan lingkungan sosial. Proporsi kedua tertinggi adalah digunakan untuk kegiatan peningkatan kualitas bahan baku. Anggaran pada program pembinaan lingkungan sosial paling banyak digunakan oleh Dinas Kesehatan yaitu untuk melengkapi fasilitas perawatan kesehatan bagi penderita akibat dampak asap rokok. Selebihnya digunakan untuk pembinaan keterampilan kerja. Seperti misalnya Kabupaten Sleman dari total anggaran 875 juta untuk program pembinaan lingkungan sosial pada tahun 2016, sebanyak 799 juta digunakan untuk kegiatan melengkapi fasilitas perawatan kesehatan bagi penderita akibat dampak asap rokok. Sisa anggaran 75 juta digunakan untuk pelatihan keterampilan dan pengelolaan manajemen usaha Industri Kecil dan Ibu Rumah Tangga di sekitar Pabrik rokok. Contoh lain yaitu Pemerintah Kabupaten Jember melakukan kegiatan pembinaan lingkungan sosial dengan menyelenggarakan beberapa kegiatan diantaranya adalah sebagai berikut:

a. Penyuluhan, pengendalian polusi dan pencemaran lingkungan hidup.

b. Pengadaan peralatan dan perbekalan kesehatan termasuk obat generik esensial.

c. Distribusi bibit ternak kepada masyarakat.

d. Diklat keterampilan bagi para pencari kerja.

e. Wirausaha baru melalui pelatihan kewirausahaan.

f. Pemberdayaan tenaga harian lepas sektor tembakau.

Penggunaan DBH CHT melalui kegiatan pembinaan lingkungan sosial diharapkan mampu mengurangi tingkat pengangguran, menurunkan tingkat kemiskinan dan mendorong pertumbuhan ekonomi daerah. Selanjutnya akan dilihat bagaimanakah gambaran tingkat 
pengangguran, tingkat kemiskinan dan pertumbuhan ekonomi daerah penerima dibandingkan dengan daerah bukan penerima. Selain itu, juga dibahas bagaimanakah gambaran tingkat pengangguran, tingkat kemiskinan dan pertumbuhan ekonomi daerah penerima DBH CHT tahun 2016 dibandingkan dengan tahun 2015.

\subsection{Implementasi DBHCHT Dilihat Berdasarkan Kacamata Perubahan Tingkat Pengangguran}

Tabel 8 menunjukkan bahwa dari tahun 2006 sampai dengan 2015, baik daerah penerima maupun yang tidak, tingkat pengangguran cenderung meningkat. Pada tahun 2014, Tingkat Pengangguran pada daerah penerima menurun sebesar 6,6\%. Pada tahun 2011 dan tahun 2014, Tingkat Pengangguran di daerah penerima juga mengalami penurunan sebesar 3,6\%. Pada tahun 2015, kenaikan Tingkat Pengangguran terbesar pada daerah bukan penerima yaitu sebesar 24,4\%, sedangkan untuk daerah penerima kenaikan Tingkat Pengangguran tertinggi terjadi pada tahun 2012 yaitu sebesar 17,1\%, tetapi kenaikan ini pun masih di bawah kenaikan Tingkat Pengangguran pada daerah bukan penerima yaitu sebesar $20,1 \%$.

Tabel 8

Persentase Perubahan Tingkat Pengangguran Daerah dari Tahun 2007 sampai dengan Tahun 2015

\begin{tabular}{lccccccccc}
\hline \multicolumn{1}{c}{ Daerah } & $\mathbf{0 7 - 0 8}$ & $\mathbf{0 8 - 0 9}$ & $\mathbf{0 9 - 1 0}$ & $\mathbf{1 0 - 1 1}$ & $\mathbf{1 1 - 1 2}$ & $\mathbf{1 2 - 1 3}$ & $\mathbf{1 3 - 1 4}$ & $\mathbf{1 4 - 1 5}$ & $\mathbf{1 5 - 1 6}$ \\
\hline $\begin{array}{l}\text { Bukan } \\
\text { Penerima }\end{array}$ & 10,9 & 0,57 & 9,62 & 0,1 & 20,1 & 0,7 & $\mathbf{- 6 , 6}$ & 24,4 & 20,56 \\
\hline Penerima & 11,5 & 2,44 & 10,8 & $\mathbf{- 3 , 6}$ & 17,1 & $\mathbf{- 3 , 6}$ & 1,4 & 6,3 & 12,58 \\
\hline \multicolumn{1}{r}{-value } & 0,852 & 0,442 & 0,620 & 0,590 & 0,450 & 0,481 & 0,103 & $\mathbf{0 , 0 0 2}$ & 0,235 \\
\hline Kesimpulan & $\begin{array}{c}\text { Tidak } \\
\text { Berbeda }\end{array}$ & $\begin{array}{c}\text { Tidak } \\
\text { Berbeda }\end{array}$ & $\begin{array}{c}\text { Tidak } \\
\text { Berbeda }\end{array}$ & $\begin{array}{c}\text { Tidak } \\
\text { Berbeda }\end{array}$ & $\begin{array}{c}\text { Tidak } \\
\text { Berbeda }\end{array}$ & $\begin{array}{c}\text { Tidak } \\
\text { Berbeda }\end{array}$ & $\begin{array}{c}\text { Tidak } \\
\text { Berbeda }\end{array}$ & $\begin{array}{c}\text { Tidak } \\
\text { Berbeda }\end{array}$ & $\begin{array}{c}\text { Tidak } \\
\text { Berbeda }\end{array}$ \\
\hline
\end{tabular}

Pada tahun 2015 baik daerah penerima maupun bukan penerima mengalami peningkatan tingkat pengangguran. Daerah bukan penerima mengalami rata-rata peningkatan sebesar $24,4 \%$ dan daerah penerima mengalami peningkatan rata-rata $6,3 \%$. Setelah dilakukan pengujian rata-rata, didapatkan kesimpulan jika rata-rata peningkatan tingkat pengangguran antara daerah penerima dan bukan penerima adalah berbeda secara statistik. Daerah yang menerima DBH CHT memiliki rata-rata peningkatan pengangguran yang lebih rendah daripada daerah bukan penerima. Hal ini lah yang menjadi dilema pemerintah. Semakin meningkatnya jumlah perokok, industri rokok akan terjaga. Semakin banyak perokok maka penerimaan cukai tembakau semakin meningkat, secara otomatis penerimaan negara meningkat. Namun, dampak terhadap efek negatif rokok akan semakin meningkat. Efek negatif rokok tidak hanya pada kesehatan tetapi juga pada semakin besarnya biaya yang dikeluarkan oleh masyarakat dan negara untuk menangani masalah kesehatan yang diakibatkan rokok. Selain itu, seseorang yang merokok maka produktifitasnya akan lebih rendah dibandingkan dengan yang tidak merokok. Tentunya hal ini akan berdampak pada produktifitas nasional. 
Tabel 9

Perubahan Tingkat Pengangguran Tahun 2015 dan Tahun 2016

\begin{tabular}{|c|l|c|c|c|c|}
\hline \multirow{2}{*}{ No } & \multicolumn{1}{|c|}{ Propinsi } & \multicolumn{2}{c|}{$\begin{array}{c}\text { Perubahan } \\
\text { Agustus } 2015 \text { ke }\end{array}$} & \multicolumn{2}{c|}{$\begin{array}{c}\text { Perubahan } \\
\text { Februari 2016 ke } \\
\text { Agustus } 2016\end{array}$} \\
\hline 1 & Aceh & -28.46 & Naik & 6.89 & Turun \\
\hline 2 & Sumatera Utara & -5.01 & Naik & 10.02 & Turun \\
\hline 3 & Sumatera Barat & -15.03 & Naik & 12.39 & Turun \\
\hline 4 & Jambi & -58.97 & Naik & 14.16 & Turun \\
\hline 5 & Sumatera Selatan & -20.68 & Naik & -9.39 & Naik \\
\hline 6 & Lampung & -49.42 & Naik & -1.76 & Naik \\
\hline 7 & Kepulauan Riau & 31.49 & Turun & 14.84 & Turun \\
\hline 8 & Jawa Barat & -3.81 & Naik & -3.73 & Naik \\
\hline 9 & Jawa Tengah & 6.03 & Turun & -10.24 & Naik \\
\hline 10 & DI Yogyakarta & 0.00 & Tetap & 3.20 & Turun \\
\hline 11 & Jawa Timur & -3.71 & Naik & -1.69 & Naik \\
\hline 12 & Bali & -45.26 & Naik & 10.85 & Turun \\
\hline 13 & Nusa Tenggara Barat & -14.26 & Naik & -7.65 & Naik \\
\hline 14 & Nusa Tengggara Timur & -22.76 & Naik & 9.47 & Turun \\
\hline 15 & Sulawesi Tengah & -37.12 & Naik & 4.91 & Turun \\
\hline 16 & Sulawesi Selatan & -2.41 & Naik & 6.07 & Turun \\
\hline
\end{tabular}

Tabel 9 menunjukkan bahwa tingkat pengangguran pada 14 provinsi dari 16 provinsi penerima mengalami peningkatan. Sedangkan pada tahun 2016, perubahan cukup signifikan yaitu dari 17 provinsi penerima hanya tujuh provinsi yang mengalami peningkatan. Rata-rata perubahan tingkat pengangguran pada tahun 2015 adalah meningkat sebesar $0,52 \%$ dan pada tahun
2016 rata-rata menurun $0,22 \%$. Setelah dilakukan pengujian didapatkan kesimpulan bahwa perubahan tingkat pengangguran tahun 2015 berbeda dengan perubahan tingkat pengangguran pada tahun 2016. Pada tahun 2016 tingkat pengangguran pada provinsi penerima mengalami penurunan.

Tabel 10

Hasil Pengujian Rata-Rata Perubahan Tingkat Pengangguran Tahun 2015 dan Tahun 2016

\begin{tabular}{lrr}
\hline & Tahun 2015 & Tahun 2016 \\
\hline Mean & $-0,5231$ & 0,22 \\
Variance & 1,26 & 0,235 \\
Observations & 16 & 16 \\
Hypothesized Mean & & \\
Difference & 0 & \\
df & 20 & \\
t Stat & $-2,429$ & \\
$\mathrm{P}(\mathrm{T}<=\mathrm{t})$ one-tail & 0.0247 & \\
\hline
\end{tabular}




\subsection{Implementasi DBHCHT Dilihat Berdasarkan Kacamata} Perubahan Tingkat Kemiskinan

Tabel 11 menunjukkan bahwa tingkat kemiskinan dari tahun 2006 sampai dengan tahun 2012 cenderung mengalami peningkatan baik di daerah penerima maupun yang tidak. Namun, pada tahun 2012 sampai dengan tahun 2016 tingkat kemiskinan cenderung menurun. Penurunan terbesar terjadi pada tahun 2015 ke tahun 2016 pada daerah penerima yaitu rata-rata sebesar $3,98 \%$.

Tabel 11

Persentase Perubahan Tingkat Kemiskinan Daerah dari Tahun 2006 sampai dengan

Tahun 2015

\begin{tabular}{|c|c|c|c|c|c|c|c|c|c|c|}
\hline Daerah & 06-07 & 07-08 & 08-09 & 09-10 & 10-11 & 11-12 & $12-13$ & 13-14 & 14-15 & $15-16$ \\
\hline $\begin{array}{l}\text { Bukan } \\
\text { Penerima }\end{array}$ & 14,9 & 10,6 & 0,99 & 10,1 & 1,9 & 18,7 & $-1,2$ & $-1,84$ & $-2,4$ & $-2,25$ \\
\hline Penerima & 12,7 & 11,2 & 1,59 & 10,0 & $-3,2$ & 17,9 & $-1,3$ & $-0,70$ & $-3,67$ & $-3,98$ \\
\hline \multicolumn{11}{|c|}{ Hasil Uji Hipotesis } \\
\hline$P$-value & 0,557 & 0,844 & 0,804 & 0,964 & 0,415 & 0,850 & 0,907 & 0,096 & 0,530 & 0,398 \\
\hline Kesimpulan & $\begin{array}{c}\text { Tidak } \\
\text { Berbeda }\end{array}$ & $\begin{array}{c}\text { Tidak } \\
\text { Berbeda }\end{array}$ & $\begin{array}{c}\text { Tidak } \\
\text { Berbeda } \\
\end{array}$ & $\begin{array}{c}\text { Tidak } \\
\text { Berbeda } \\
\end{array}$ & $\begin{array}{c}\text { Tidak } \\
\text { Berbeda }\end{array}$ & $\begin{array}{c}\text { Tidak } \\
\text { Berbeda }\end{array}$ & $\begin{array}{c}\text { Tidak } \\
\text { Berbeda }\end{array}$ & $\begin{array}{c}\text { Tidak } \\
\text { Berbeda }\end{array}$ & $\begin{array}{c}\text { Tidak } \\
\text { Berbeda }\end{array}$ & $\begin{array}{c}\text { Tidak } \\
\text { Berbeda } \\
\end{array}$ \\
\hline
\end{tabular}

Berdasarkan hasil pengujian rata-rata perubahan tingkat kemiskinan, perubahan tingkat kemiskinan baik di daerah penerima maupun daerah bukan penerima disimpulkan tidak berbeda secara statistik. Jika ditinjau dari rata-rata perubahan, dari tahun 2012 sampai dengan tahun 2016 rata-rata penurunan tingkat kemiskinan pada daerah penerima lebih besar jika dibandingkan dengan daerah bukan penerima. Sedangkan pada tahun 2006 sampai dengan tahun 2012 tingkat kemiskinan cenderung meningkat pada daerah penerima maupun daerah bukan penerima. Peningkatan pada daerah bukan penerima cenderung lebih tinggi jika dibandingkan dengan daerah penerima alokasi DBH CHT.

Tabel 12

Perubahan Tingkat Kemiskinan Tahun 2015 dan Tahun 2016

\begin{tabular}{|c|l|c|c|c|c|}
\multirow{2}{*}{ No } & \multicolumn{1}{|c|}{ Propinsi } & \multicolumn{2}{c|}{$\begin{array}{c}\text { Perubahan } \\
\text { Februari } 2015 \text { ke } \\
\text { Agustus } 2015\end{array}$} & \multicolumn{2}{c|}{$\begin{array}{c}\text { Perubahan Februari } \\
2016 \text { ke Agustus }\end{array}$} \\
& & -0.18 & Naik & 1.79 & Turun \\
\hline 1 & Aceh & -2.47 & Naik & 0.77 & Turun \\
\hline 2 & Sumatera Utara & 8.21 & Turun & -0.71 & Naik \\
\hline 3 & Sumatera Barat & -2.93 & Naik & 0.48 & Turun \\
\hline 4 & Jambi & 3.37 & Turun & 1.11 & Turun \\
\hline 5 & Sumatera Selatan & 5.71 & Turun & 3.01 & Turun \\
\hline 6 & Lampung & 7.37 & Turun & 2.34 & Turun \\
\hline 7 & Kepulauan Riau & -0.42 & Naik & 2.01 & Turun \\
\hline 8 & Jawa Barat & 1.91 & Turun & 0.60 & Turun \\
\hline 9 & Jawa Tengah & 11.74 & Turun & 1.80 & Turun \\
\hline 10 & DI Yogyakarta & 0.49 & Turun & 1.66 & Turun \\
\hline 11 & Jawa Timur & & & & \\
\hline
\end{tabular}




\begin{tabular}{|c|l|c|c|c|c|}
\hline 12 & Bali & -10.76 & Naik & 2.35 & Turun \\
\hline 13 & Nusa Tenggara Barat & 3.27 & Turun & 2.79 & Turun \\
\hline 14 & Nusa Tengggara Timur & 0.13 & Turun & 0.81 & Turun \\
\hline 16 & Sulawesi Tengah & 4.02 & Turun & 2.49 & Turun \\
\hline 17 & Sulawesi Selatan & -7.77 & Naik & 1.70 & Turun \\
\hline
\end{tabular}

Tabel 12 menunjukkan bahwa tingkat kemiskinan pada enam provinsi dari 16 provinsi penerima mengalami peningkatan. Sedangkan pada tahun 2016, perubahan cukup signifikan yaitu dari 16 provinsi penerima hanya satu provinsi yang mengalami peningkatan yaitu provinsi Sumatera Barat. Rata-rata perubahan tingkat pengangguran pada tahun 2015 adalah menurun sebesar $1,356 \%$ dan pada tahun 2016 rata-rata menurun $1,564 \%$. Setelah dilakukan pengujian didapatkan kesimpulan bahwa perubahan tingkat kemiskinan tahun 2015 tidak berbeda dengan perubahan tingkat kemiskinan pada tahun 2016.

Tabel 13

Hasil Pengujian Rata-Rata Perubahan Tingkat Kemiskinan Tahun 2015 dan Tahun 2016

\begin{tabular}{lrr}
\hline & Tahun 2015 & Tahun 2016 \\
\hline Mean & 1.356 & 1.564 \\
Variance & 33,07 & 0,978 \\
Observations & 16 & 16 \\
Hypothesized Mean & & \\
Difference & 0 & \\
df & 16 & \\
$\mathrm{t}$ Stat & -0.142 & \\
$\mathrm{P}(\mathrm{T}<=\mathrm{t})$ one-tail & 0.889 & \\
\hline
\end{tabular}

\subsection{Implementasi DBHCHT Dilihat Berdasarkan Kacamata}

\section{Pertumbuhan Ekonomi}

Tabel 14 menunjukkan bahwa dari tahun 2006 sampai dengan 2016, pertumbuhan ekonomi meningkat, namun jika dilihat persentase peningkatan dari tahun ke tahun cenderung makin menurun. Kenaikan pertumbuhan ekonomi paling tinggi pada daerah bukan penerima alokasi DBH CHT yaitu terjadi pada tahun 2009 sebesar 6,51\% dan pada daerah penerima alokasi DBH CHT pada tahun 2008 yaitu sebesar 5,59\%.

Tabel 14

Persentase Perubahan Tingkat Pertumbuhan Ekonomi Daerah dari Tahun 2006 sampai dengan Tahun 2015

\begin{tabular}{|c|c|c|c|c|c|c|c|c|c|c|}
\hline Daerah & 06-07 & 07-08 & 08-09 & $09-10$ & $10-11$ & $11-12$ & $12-13$ & $13-14$ & $14-15$ & $15-16$ \\
\hline $\begin{array}{l}\text { Bukan } \\
\text { Penerima }\end{array}$ & 5,58 & 5,88 & 6,51 & 5,85 & 4,06 & 4,31 & 4,25 & 3,59 & 3,39 & 2,92 \\
\hline Penerima & 5,27 & 5,59 & 5,46 & 4,95 & 4,24 & 4,51 & 4,54 & 3,96 & 5,13 & 4,08 \\
\hline \multicolumn{11}{|c|}{ Hasil Uji Hipotesis } \\
\hline$P$-value & 0,534 & 0,683 & 0,683 & 0,427 & 0,879 & 0,821 & 0,602 & 0,517 & 0,214 & 0,07 \\
\hline Kesimpulan & $\begin{array}{c}\text { Tidak } \\
\text { berbeda }\end{array}$ & $\begin{array}{c}\text { Tidak } \\
\text { Berbeda }\end{array}$ & $\begin{array}{c}\text { Tidak } \\
\text { Berbeda }\end{array}$ & $\begin{array}{c}\text { Tidak } \\
\text { Berbeda }\end{array}$ & $\begin{array}{c}\text { Tidak } \\
\text { Berbeda }\end{array}$ & $\begin{array}{c}\text { Tidak } \\
\text { Berbeda }\end{array}$ & $\begin{array}{c}\text { Tidak } \\
\text { Berbeda }\end{array}$ & $\begin{array}{c}\text { Tidak } \\
\text { Berbeda }\end{array}$ & $\begin{array}{c}\text { Tidak } \\
\text { Berbeda }\end{array}$ & $\begin{array}{c}\text { Tidak } \\
\text { Berbeda }\end{array}$ \\
\hline
\end{tabular}


Tabel 15

Perubahan Tingkat Pertumbuhan Ekonomi Tahun 2015 dan Tahun 2016

\begin{tabular}{|c|l|c|c|c|c|}
\hline No & \multicolumn{1}{|c|}{ Propinsi } & \multicolumn{2}{c|}{$\begin{array}{c}\text { Perubahan } \\
\text { Tahun 2014 ke } \\
\text { Tahun 2015 }\end{array}$} & $\begin{array}{c}\text { Perubahan } \\
\text { Tahun } 2015 \text { ke } \\
\text { Tahun } 2016\end{array}$ \\
\hline 1 & Aceh & 2.62 & Turun & -1.38 & Naik \\
\hline 2 & Sumatera Utara & -3.81 & Naik & -3.79 & Naik \\
\hline 3 & Sumatera Barat & -4.21 & Naik & -3.84 & Naik \\
\hline 4 & Jambi & -2.44 & Naik & -2.58 & Naik \\
\hline 5 & Sumatera Selatan & -2.98 & Naik & -3.50 & Naik \\
\hline 6 & Lampung & -3.95 & Naik & -3.87 & Naik \\
\hline 7 & Kepulauan Riau & -3.02 & Naik & -2.13 & Naik \\
\hline 8 & Jawa Barat & -3.51 & Naik & -4.01 & Naik \\
\hline 9 & Jawa Tengah & -4.68 & Naik & -4.33 & Naik \\
\hline 10 & DI Yogyakarta & -3.75 & Naik & -3.73 & Naik \\
\hline 11 & Jawa Timur & -4.80 & Naik & -4.70 & Naik \\
\hline 12 & Bali & -4.81 & Naik & -4.81 & Naik \\
\hline 13 & Nusa Tenggara Barat & -20.21 & Naik & -4.32 & Naik \\
\hline 14 & Nusa Tengggara Timur & -3.33 & Naik & -3.38 & Naik \\
\hline 15 & Sulawesi Tengah & -13.70 & Naik & -7.65 & Naik \\
\hline 16 & Sulawesi Selatan & -6.06 & Naik & -5.96 & Naik \\
\hline
\end{tabular}

Tabel 15 menunjukkan bahwa pertumbuhan ekonomi pada daerah penerima cenderung meningkat, dari 16 provinsi penerima hanya satu yang mengalami penurunan yaitu provinsi Aceh. Sedangkan pada tahun 2016, perubahan cukup signifikan yaitu dari 16 provinsi seluruhnya mengalami peningkatan. Rata-rata pertumbuhan ekonomi pada tahun 2015 adalah meningkat sebesar $5,16 \%$ dan pada tahun 2016 rata-rata meningkat 3,99\%. Setelah dilakukan pengujian didapatkan kesimpulan bahwa perubahan tingkat kemiskinan tahun 2015 tidak berbeda dengan perubahan tingkat kemiskinan pada tahun 2016 .

Tabel 16

Hasil Pengujian Rata-Rata Pertumbuhan Ekonomi Tahun 2015 dan Tahun 2016

\begin{tabular}{lrr}
\hline & Tahun 2015 & Tahun 2016 \\
\hline Mean & -5.16 & -3.998 \\
Variance & 26,02 & 2,11 \\
Observations & 16 & 16 \\
Hypothesized Mean & & \\
Difference & 0 & \\
Df & 19 & \\
$\mathrm{t}$ Stat & -0.879 & \\
$\mathrm{P}(\mathrm{T}<=\mathrm{t})$ one-tail & 0.391 & \\
\hline
\end{tabular}


Tabel 14 menunjukkan baik di daerah penerima maupun yang tidak menerima ternyata tingkat pertumbuhan ekonomi mengalami kenaikan. Berdasarkan statistika deskriptif pada Tabel 14 dapat dilihat bahwa persentase kenaikan pertumbuhan ekonomi pada daerah yang menerima alokasi DBH CHT cenderung lebih tinggi dibandingkan dengan daerah yang tidak menerima alokasi DBH CHT.

\section{Pertumbuhan}

ekonomi

meningkat, namun tingkat pengangguran juga meningkat. Hal ini tidak sesuai dengan makroekonomi yang menyatakan bahwa pertumbuhan ekonomi meningkat, maka tingkat pengangguran akan turun. Hal ini disebabkan karena investasi meningkat, namun investasi yang padat modal dan teknologi sehingga menyerap sedikit tenaga kerja. Selain itu, juga karena berlakunya perjanjian perdagangan bebas antara ASEAN dan China (ACFTA). Adanya perjanjian ini menjadi tantangan bagi sejumlah daerah dikarenakan daya saing produk-produk lokal masih tertinggal dengan produkproduk China. Pasar domestik menjadi sasaran empuk produk China yang harganya lebih murah dibanding produk lokal sehingga banyak perusahaanperusahaan kecil yang tutup karena tidak bisa bersaing dan mau tidak mau berimbas pada banyaknya karyawan yang kehilangan pekerjaan.

\section{KESIMPULAN DAN SARAN}

\subsection{Kesimpulan}

Berdasarkan analisis dan pembahasan, dapat ditarik beberapa kesimpulan yaitu sebagai berikut:

a. Dari tahun 2012 sampai dengan 2016, tingkat pengangguran cenderung meningkat, baik pada daerah penerima maupun bukan penerima. Rata-rata peningkatan tingkat pengangguran pada daerah penerima lebih rendah dibandingkan daerah bukan penerima yaitu $6,756 \%$, sedangkan daerah bukan penerima rata-rata peningkatannya adalah $11,83 \%$.

b. Dari tahun 2012 sampai dengan tahun 2016, tingkat kemiskinan cenderung menurun. Penurunan tingkat kemiskinan pada daerah penerima lebih besar jika dibandingkan dengan daerah bukan penerima yaitu 2,4\%, sedangkan daerah bukan penerima turun ratarata $2,1 \%$.

c. Dari tahun 2012 sampai dengan tahun 2016, pertumbuhan ekonomi baik pada daerah penerima maupun bukan penerima mengalami peningkatan. Peningkatan pertumbuhan ekonomi pada daerah penerima lebih tinggi dibandingkan dengan daerah bukan penerima yaitu 4,44\%, sedangkan pada daerah bukan penerima adalah $3,69 \%$.

\subsection{Saran}

Berdasarkan kesimpulan yang didapatkan, dapat diberikan beberapa saran sebagai berikut:

a. Pemberian DBH CHT seharusnya diberikan kepada seluruh provinsi di Indonesia, mengingat distribusi rokok dilakukan di seluruh provinsi di Indonesia dan dampak negatif rokok juga perlu diantisipasi oleh seluruh provinsi di Indonesia.

b. Tingkat Pengangguran merupakan salah satu masalah yang cukup besar buat Negara Indonesia. Salah satu industri yang banyak menyerap tenaga kerja adalah industri rokok. Hal ini merupakan dilema pemerintah, namun jika dilihat dari dampak yang diakibatkan rokok pemerintah harus segera memikirkan langkah untuk mengurangi ketergantungan terhadap industri rokok. Seperti halnya dengan 
memberikan pelatihan kepada masyarakat terutama di sekitar industri rokok, agar tidak sangat bergantung pada keberlangsungan industri rokok.

c. Dengan adanya beberapa ketidaksesuaian penggunaan anggaran DBH CHT, Kementerian Keuangan harus meningkatkan evaluasi dan monitoring terhadap penggunaan anggaran DBH CHT.

d. Setiap daerah penerima alokasi DBH CHT diwajibkan untuk melaporkan detail kegiatan yang didanai $\mathrm{DBH}$ CHT secara tepat waktu, sehingga monitoring akan lebih mudah dilakukan.

e. Penambahan alokasi DBH CHT yang dikhususkan untuk dana pendidikan yang dikhususkan untuk memberikan sosialisasi kepada pelajar tentang rokok.

\section{DAFTAR PUSTAKA}

Boediono, 1999, Teori Pertumbuhan Ekonomi, Yogyakarta: BPFE

Cahya Rosalia, dkk. 2014. Implementasi Kebijakan Penggunaan Dana Bagi Hasil Cukai Hasil Tembakau (DBH CHT) di Kabupaten Jember. Universitas Negeri Jember.

Case, dan Fair. 2004. Prinsip-prinsip Ekonomi Makro. 7rded. Jakarta: PT INDEKS.

Kementerian Kesehatan. 2012. Buku Panduan Penggunaan Dana Bagi Hasil Cukai Hasil Tembakau (DBH CHT) di Bidang Kesehatan.

Kementerian Kesehatan. 2017. Profil Kesehatan Indonesia Tahun 2016.

Sitepu, E.M.P.Kajian Ekonomi \& Keuangan Vol. 23 No.3 (Desember 2016).

World Health Organization. (2008). WHO Report on the Global Tobacco Epidemic. Geneva: WHO Press.
Walpole, Ronald E dan Myers, Raymond H. 1995. Ilmu Peluang dan Statistika Untuk Insinyur dan Ilmuwan. Edisi ke-4. Bandung: ITB.

\section{Peraturan Perundang-undangan}

Kementerian Keuangan. (2009). PMK Nomor 20/PMK.07/2009 tentang Perubahan atas Peraturan Menteri Keuangan Nomor 84/PMK.07/2008 tentang Penggunaan Dana Bagi Hasil Cukai Hasil Tembakau dan Sanksi atas Penyalahgunaan Alokasi Dana Bagi Hasil Cukai Hasil Tembakau.

Kementerian Keuangan. (2014). PMK Nomor 216/PMK.07/2014 tentang Perubahan Atas Peraturan Menteri Keuangan Nomor 106/PMK.07/2014 tentang Perkiraan Alokasi Dana Bagi Hasil Cukai Hasil Tembakau Tahun Anggaran 2014.

Kementerian Keuangan. (2016). PMK Nomor 28/PMK.07/2016 tentang Penggunaan, Pemantauan, dan Evaluasi Dana Bagi Hasil Cukai Hasil Tembakau. 